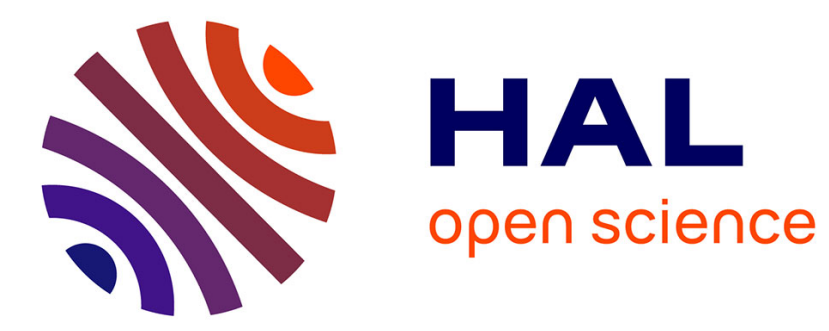

\title{
Ban Non Wat: Mainland Southeast Asian Chronological Anchor and Waypoint for Future Prehistoric Research
} Thomas Oliver Pryce

\section{To cite this version:}

Thomas Oliver Pryce. Ban Non Wat: Mainland Southeast Asian Chronological Anchor and Waypoint for Future Prehistoric Research. Antiquity, 2015, 89 (347), pp.1227-1229. 10.15184/aqy.2015.107 . hal-01529093

\section{HAL Id: hal-01529093 \\ https://hal.parisnanterre.fr/hal-01529093}

Submitted on 4 Oct 2017

HAL is a multi-disciplinary open access archive for the deposit and dissemination of scientific research documents, whether they are published or not. The documents may come from teaching and research institutions in France or abroad, or from public or private research centers.
L'archive ouverte pluridisciplinaire HAL, est destinée au dépôt et à la diffusion de documents scientifiques de niveau recherche, publiés ou non, émanant des établissements d'enseignement et de recherche français ou étrangers, des laboratoires publics ou privés. 


\title{
Ban Non Wat: Mainland Southeast
} Asian chronological anchor and waypoint for future prehistoric research

\author{
Thomas Oliver Pryce*
}

The timing and nature of Southeast Asia's Neolithic and Bronze Ages have been the source of global archaeological intrigue, scepticism (on occasion) and even notoriety for some five decades (e.g. Muhly 1981). Being asked to review an account of what has been an emotive topic provoked a personal response, which I hope may contribute to highlighting the impact of Charles Higham's work, and that of his many colleagues.

My course in Southeast Asian prehistoric research began when I joined Vincent Pigott's and Surapol Natapintu's Thailand Archaeometallurgy Project in late 2004. This juncture corresponded with what might be called the 'second intermediate period' of Higham's radiocarbon technological development-post-organic temper but pre-bone ultrafiltration. As such, arriving for my very first excavation in Southeast Asia in January 2005 (at Ban Non Wat as it happens), I was immediately confronted by a team member with the evidently pointed question: "do you support the long or the short chronology for the Bronze Age". To which the only honest answer was, "I don't know", having not read enough about it at that stage. Clearly, there was contentious ground under foot and given that my PhD was to concentrate on the evolution of prehistoric copper-smelting behaviours at two of the region's main production sites, Non Pa Wai and Nil Kham Haeng, I reasoned I had better 20 tread carefully.

Although such wariness would generally be well-advised for a junior academic, it had not accounted for the huge upheaval in the dating of Southeast Asia's Neolithic and Bronze Age transitions during the period 2005-2014. The substantial majority of this remaking of the regional late prehistoric chronology can be directly attributed to the application of third-generation radiocarbon techniques to human bone and shell grave-goods samples by Higham and colleagues; firstly at Ban Non Wat (Higham \& Higham 2009), then Ban 27 Chiang (Higham et al. 2011) and finally Non Nok Tha (Higham et al. 2014). This fervour 28 was also replicated by the Thailand Archaeometallurgy Project, where the enthusiastic prescription of Higham's (1996: 12) 'chronometric hygiene' medicine in 2007 led to many of the original charcoal radiocarbon dates (Pigott et al. 1997) being rejected and the central and north-eastern Thai chronologies being largely harmonised (Rispoli et al. 2013; Higham \& Rispoli 2014).

At this point, my archaeometallurgical research becomes of some relevance to the regional Bronze Age debate. At the central Thai copper-production site of Non Pa Wai, I identified

\footnotetext{
* CNRS, UMR 7055 Prébistoire et Technologie, Universitéde Paris Ouest La Defense, France (Email: opryce@gmail.com) ANTIQUITY 89347 (2015): 1-3 
a potentially experimental phase of smelting concurrent with competent bronze founding, which, chronology aside, would be poorly compatible with the SCM's technological transmission mechanism of migrating experienced metalworkers; it would also be arguably closer to the LCM proposition that Southeast Asian metallurgy was stimulated by 'trade and exchange' with present-day China (Pryce et al. 2010). This impression was reinforced by the subsequent Southeast Asian Lead Isotope Project, which highlighted that the earliest eleventh century BC copper-based artefacts from Non Pa Wai and Ban Non Wat were incompatible with any known regional copper source but that within a very short period of 43 time, perhaps 50 years, locally-produced raw copper was being exchanged over at least several hundred kilometres (Pryce et al. 2014). It also transpired that some of Ban Chiang's earliest copper-based artefacts, dated by Higham to the tenth century BC, are highly consistent with the Sepon production site in central Laos, which until now has only produced Iron Age dates (Pryce et al. 2014). No Non Nok Tha samples have yet been assessed for 48 provenance.

Of course, archaeological interpretation, and science in general, is never a done deal and major new discoveries could revise the current picture, but I think we are at the stage where objective resistance to the broad brushstroke of the SCM model is no longer a realistic position. That said, there is both scope and necessity for further investigation into potentially historically significant regional variation when the current dataset is so overwhelmingly Thai. At the very least, any reasonably definitive appraisal of the sequence and nature ofcopper-base metallurgy's transmission from or via present-day China will require high-quality Bronze Age datasets from the contact zones of, west to east, northern Myanmar, Laos and Vietnam, where none exist at present. Furthermore, while Ban Non Wat is without doubt a 'great site' and its excavation has revolutionised our understanding of Southeast Asian late prehistory, I do not believe the manner of its investigation can serve as a viable regional model. Quite simply, shifting that much dirt and properly studying everything that comes out of it during long seasons, year after year, is ruinously expensive, and very few other teams, whether local or foreign, could hope to bear the burden. This could be the moment to call for even greater collaboration amongst Southeast Asian archaeologists, so that we band together to dig fewer sites more thoroughly, but there are perhaps too many competing interests now active in the region.

Finally, Charles Higham has by now struck his SCM point firmly home by a number of means on a number of occasions. Near-consensus having been achieved, at least for the time being, I fully agree with his suggestion that we concentrate our efforts on Southeast Asia's more needy archaeological lacunae. In the meantime, let us encourage the guidebooks on Southeast Asia to correct their historical background sections that are now 30 years out of date, along with the regional sections of some major national museums. Southeast Asian prehistory has so much more to give than a 50 -year-old bout of overenthusiasm.

\section{References}

Higham, C.F.W. 1996. The Bronze Age of Southeast Asia. Cambridge: Cambridge University Press.
Higham, C. F. W. \& T.F.G. Higham. 2009. A new chronological framework for prehistoric Southeast Asia, based on a Bayesian model from Ban Non Wat. Antiquity 82: 1-20. http://dx.doi.org/10.1017/s0003598x00098136 


\section{Ban Non Wat}

Higham, C.F.W. \& F. Rispoli. 2014. The Mun Valley and Central Thailand in prehistory: integrating two cultural sequences. Open Archaeology 1: 2-28. http://dx.doi.org/10.2478/opar-2014-0002

Higham, C.F.W., T.F.G. Higham \& A. Kijngam. 2011. Cutting a Gordian Knot: the Bronze Age of Southeast Asia: origins, timing and impact. Antiquity 85: 583-98. http://dx.doi.org/10.1017/S0003598X00067971

Higham, C.F.W., T.F.G. Higham \& K. Douka. 2014. The chronology and status of Non Nok Tha, northeast Thailand. Journal of Indo-Pacific Archaeology 34: 61-75. http://dx.doi.org/10.7152/jipa.v34i0.14719

MuhLy, J.D. 1981. The origin of agriculture and technology: Aarhus, Denmark, November 21-25, 1978. II. Summary: the origin of agriculture and technology-West or East Asia? I echnology and Culture 22: 125-48. http://dx.doi.org/10.2307/3104297

Pigott, V. C., A. Weiss \& S. Natapintu. 1997. Archaeology of copper production: excavations in the Khao Wong Prachan Valley, Central Thailand, in R. Ciarla \& F. Rispoli (ed.) South-east Asian Archaeology 1992: proceedings of the Fourth International Conference of the European Association of South-East Asian Archaeologists, Rome, 28th September-4th October 1992: 119-57. Rome: Istituto Italiano per l'Africa e l'Oriente.
Pryce, T.O., V.C. Pigott, M. MartinÔn-Torres \& T. ReHren. 2010. Prehistoric copper production and technological reproduction in the Khao Wong Prachan Valley of Central Thailand. Archaeological and Anthropological Sciences 2: 237-64. http://dx.doi.org/10.1007/s12520-010-0043-y

Pryce, T.O., S. Baron, B.H.M. Bellina, P.S. Bellwood, N. Chang, P. Chattopadhyay, E. Dizon, I.C. Glover, E. Hamilton, C.F.W. Higham, A.A. Kyaw, V. Laychour, S. Natapintu, V. Nguyen, J.-P. Pautreau, E. Pernicka, V.C. Pigott, M. Pollard, C. Pottier, A. Reineckep, T. Sayavongkhamdy, V. Souksavatdy \& J. White. 2014. More questions than answers: the Southeast Asian Lead Isotope Project 2009-2012. Journal of Archaeological Science 42: 273-94. http://dx.doi.org/10.1016/j.jas.2013.08.024

Rispoli, F., R. Ciarla \& V.C. Pigotт. 2013.

Establishing the prehistoric cultural sequence for the Lopburi reg1on, central I halland. Journal of World Prebistory 26: 101-71.

http://dx.doi.org/10.1007/s10963-013-9064-7 